\title{
Forms of Slavery and Patterns of Slave Holding in Urban Mozambique in the 1820s
}

\author{
Filipa Ribeiro da Silva
}

\section{Introduction ${ }^{1}$}

Over the last forty years, the topics of slavery and slave trade in the Indian Ocean World (IOW) have received a greater deal of attention from scholars specialized on the various regions touched by this vast water mass, East Africa and Mozambique being no exceptions. ${ }^{2}$ This interest led to the production of an extensive body of literature and a lively debate mainly dominated by four questions: i) what were the meanings of 'slave' and 'slavery' in the IOW? ii) what were the multiple forms of slave labor in the IOW and how did they compare? iii) How did slave labor co-exist with other forms of coerced labor? And iv) how did the slave trade and slavery in the IOW compare with the same phenomena in the Atlantic World? ${ }^{3}$

Although, as Gwyn Campbell stated earlier "there is [still] no consensus as to the meaning of slavery in the IOW"4, it is now commonly accepted that this vast area of the globe was home to different groups of servile workers,

\footnotetext{
${ }^{1}$ The research that forms the basis of this study was carried out within the framework of three research projects: the Global Collaboratory on the History of Labour Relations, 15002000 , hosted by the International Institute of Social History and sponsored by the Gerda Henkel Foundation and the Netherlands Organization for Scientific Research (NWO); the Labour Relations in Portugal and the Lusophone World, 1800-2000: Continuities and Changes project; and the Counting Colonial Populations: Demography and the Use of Statistics in the Portuguese Empire, 1776-1890 project, both sponsored by the Portuguese Foundation for Science and Technology. The author would also like to thank the research assistants of the Counting Colonial Populations project - Diogo Felipe Paiva and Patrícia Gomes Lucas - for their archive research; and Paulo Teodoro de Matos, Jan Kok and Kees Mandemakers reading earlier drafts of this study and for their valuable suggestions. Finally, the author would like to express his gratitude to the editors of this volume, to the anonymous peer-reviewers and all participants in the Kalmar workshop, where a draft of this study was presented and discussed, for their valuable feedback and suggestions. The author is responsible for any mistakes.

${ }^{2}$ See among others: Pedro Machado, "A Forgotten Corner of the Indian Ocean: Gujarati Merchants, Portuguese Indian and the Mozambique Slav-Trade, c. 1730-1830," Slavery \& Abolition, 24:2 (2003):17-32; and Allen F. Isaacman and Barbara S. Isaacman, Slavery and Beyond: The Making of Men and Chikunda Ethnic Identities in the Unstable World of South-Central Africa, 1750-1920 (Portsmouth: Heinemann, 2004).

${ }^{3}$ For an overview of this scholarly production and its main debates, see: Gwyn Campbell, "The Question of Slavery in Indian Ocean World History" in Abdul Sheriff and Engseng Ho, eds., The Indian Ocean: Ocean Connections and the Creation of New Societies (London: Hurst \& Company, 2014), 123-150.

${ }^{4}$ Gwyn Campbell, "Servitude and the changing face of demand for labor in the Indian Ocean world, c. 1800-1900" in Robert W. Harms, Bernard K. Freamon, David W. Blight, eds., Indian Ocean Slavery in the Age of Abolition (New Haven: Yale University Press, 2013), 12.
} 
including not only enslaved people, but also other servile laborers such as corvée- and debt-bonded workers, among others. It is also widely acknowledged that slavery took different shapes determined not only by the lack of freedom of a person, but also by his or her function, as well as by the context in which a slave lived and worked, such as the distinction between rural and urban spaces or between domestic service and plantation work. The ties slaves maintained with their masters, as well as with the people found in other forms of dependency appeared to have also been paramount in defining their social and economic status, making clear the distinctions between chattel-slavery, client slavery, pawnship, etc. East Africa and more specifically Mozambique are cases in point, as slavery took multiple forms here, and slaves coexisted side-by-side with other dependent workers.

In nineteenth-century Mozambique, this coexistence becomes rather evident through the analysis of a small collection of individual household and estate surveys (as way of example see Illustration 1), and a set of nominal population counts (as way of example see Illustration 2), carried out by officials of Portuguese Crown in the Mozambican territory under their control, including both rural and urban settings. ${ }^{5}$ On 25 May 1820, for example, Francisco João da Costa Xavier, a lieutenant of the militia in the town of Tete (Mozambique) and resident there, sent his attorney José Ferreira Rodrigues to attend the local representative of the Portuguese Crown. The purpose was to provide information about his household, estate and assets and Rodrigues declared that lieutenant Xavier owned 220 slaves, 120 of whom lived on his estate and 100 of whom were absent. Equal numbers of men and women were listed. Xavier's estate, named Terra Jnadoa and held in tenancy from the Portuguese Crown, had come to him on his marriage to Madame Paula Gertrudes de Aragão, and was home also to five or six villages of nonenslaved African dependents (named colonos as well as colonos forros in the Portuguese sources). The colonos forros produced maize, for which the tenants received 10 alqueires $^{6}$ from each colono and six cotton cloths (machilas de gondo) in return for their use of the oven located on the same estate and for protection. ${ }^{7}$ Like lieutenant Xavier, many other descendants of Portuguese inhabitants provided similar particulars to the officials of the Portuguese Crown in the territory, as did Banyan merchants of Indian origin and Swahili residents. Xavier lived in Tete, but the same pattern was repeated by many other individuals in other Mozambican towns under Portuguese

\footnotetext{
${ }^{5}$ These materials are currently deposited in the collections of the Portuguese Overseas Historical Archive (hereafter AHU - Arquivo Histórico Ultramarino) and the Portuguese National Archive/Torre do Tombo (hereafter AN/TT).

${ }^{6}$ Measure of capacity used for grains. 1 alqueire $=$ circa 13 kilograms.

${ }^{7}$ Portuguese Overseas Historical Archive (hereafter AHU), Mozambique, cx. 174, doc. 68 : "Mapa Circunstanciado da Casa de Francisco João da Costa Xavier como se vê da maneira seguinte" (see Illustration 1). Machila was a commonly used means of transport for Europeans and wealthy people all over the Portuguese Empire in the eighteenth and nineteenth centuries, including in Angola and Mozambique.
} 
control. The information was used to produce a series of household and estate surveys as well as population counts for the Portuguese as part of a major initiative by the Portuguese Crown in the 1770s to register all subjects of the Empire with the aim of expanding royal power and extracting wealth and labor. ${ }^{8}$ The population tables produced then contain names of household members, marital status, age and place of birth, relationship of each household member to the head of the household, and the profession of the head of the household. Details of the amount of property held by each household, including slaves living in the urban centers or as dependents of the urban residents, as well as dwellings, fields and livestock are included too. The total number of adult male and females and child slaves was given for each household, although no names, ages, marital status, family ties nor trades were recorded.

Despite being known for more than fifty years to scholars interested in the history of Mozambique and the surrounding region, and despite the richness of the information available in these source materials on slavery and other forms of dependency, none of it has yet been used to study the slave population of urban Mozambique, the forms of enslavement in the main towns and their outskirts, slavery's coexistence with other forms of dependency, nor to trace the profile of the masters of these slaves and their patterns of slave ownership, as well as their role as patrons or superiors of other dependent workers. ${ }^{9}$ These will be the main goals of this study and its contribution to the broader debate on slavery in the IOW.

\footnotetext{
${ }^{8}$ These source materials were recently located, transcribed, and made available online by the Research Project: Counting Colonial Populations: Demography and the use of Statistics in the Portuguese Empire, 1776-1875. This initiative was sponsored by the Portuguese Foundation for Science and Technology and coordinated by Paulo Teodoro de Matos (NOVA University of Lisbon, Portugal). This project aimed to identify and analyze the dominant demographic patterns in the Portuguese empire between 1776 and 1875, and to explain how population statistics became instrumental in the consolidation of Portuguese colonies in Africa, Asia, and the Americas. The project's main goals were: i) to identify and reconstruct the main demographic indicators of colonial populations; ii) to distinguish and explain the existing demographic regimes; iii) to reconstruct the bureaucratic network used in the production and collection of statistical information and to identify the evolution of population categories; and iv) to assess how the statistics responded to the needs of the colonial administration at military and fiscal level, and in terms of territorial occupation. Further information on datasets, and outputs may be found on: http://colonialpopulations.fcsh.unl.pt/mainEnglish.html

${ }^{9}$ These demographic sources have been used mainly to provide a portrait of the territory's population, and to study topics such as the formation of the Prazo System, labor recruitment, migration patterns, and household structures during the precolonial period. Additionally, they have been examined as an object of study per se, with scholars paying special attention to the source production process, and the problems of reliability posed by these materials to researchers. Among the scholars who have worked with some of these materials are Malyn Newitt, Allen Isaacman, Eugénia Rodrigues, and Rudy Bauss, Ana Paula Wagner, to mention just a few. Allen Isaacman, Mozambique: The Africanication of a European Institution: The Zambezi Prazos, 1750-1902 (Madison, Wisc.: The University of Wisconsin Press, 1972); Rudy Bauss, "A Demographic Study of Portuguese India and Macau as well as comments on Mozambique and Timor, 1750-1850," The Indian Economic and Social History Review 34.2 (1997); Eugénia Rodrigues, Portugueses e Africanos nos
} 
Illustration 1: Household Bulletin with information on family and propriety, including enslaved Africans

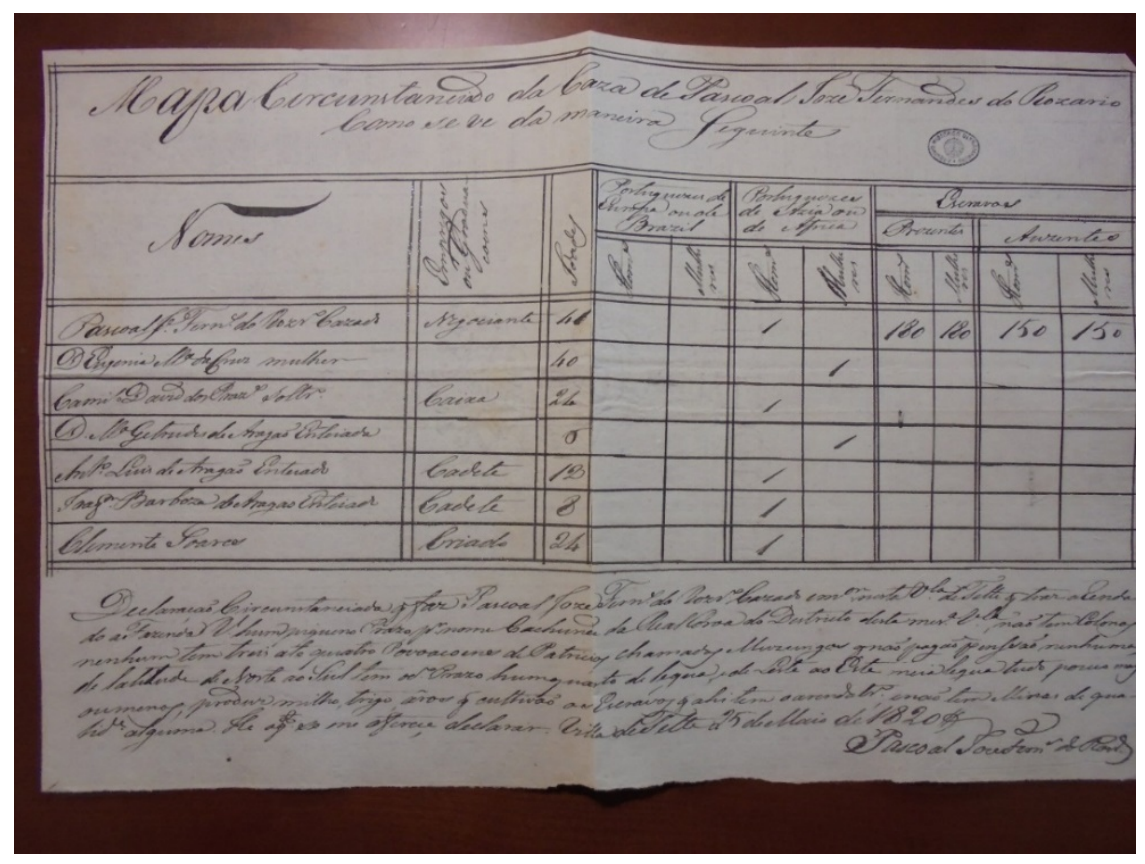

Sources: AHU, Moçambique, cx. 174, doc. 68

To date, the scholarship on Mozambique's economic and social history, and particularly on slavery and the slave trade, has to a great extent been divided into two main streams. On the one hand, there is a body of literature focused on so-called 'traditional' forms of slavery and other forms of dependence, while on the other hand there are studies devoted mainly to the trade in slaves. The literature on slavery itself has focused mainly on the study of African systems of slavery and other forms of dependency of free people within the framework of African chieftaincies, as well as in the context of Portuguese settlement on the Mozambican coast and the formation of the so-called Prazo

Rios de Sena: Os Prazos da Coroa em Moçambique nos Séculos XVII e XVIII (Lisboa: Imprensa Nacional - Casa da Moeda, 2013); Ana Paula Wagner, População no Império Português: Recenseamentos na África Oriental Portuguesa na segunda metade do século XVIII (Ph.D. diss., Universidade Federal do Paraná, Curitiba, 2009). Filipa Ribeiro da Silva, "From Church records to royal population charts: The birth of "modern demographic statistics" in Mozambique, 1720s-1820s,"Anais de História de Além-Mar 16 (2015): 17-50. 
system ${ }^{10}$ in the Zambezi Valley. ${ }^{11}$ These studies have made clear the existence of client-slavery and a "open slavery system" in the region, as well as the client-patron relationships between local elites and non-enslaved dependent workers. ${ }^{12}$ The literature on slave trading, on the other hand, has been centered on the trade between Mozambique and the Indian sub-continent in particular Goa, as well as on the trade between Mozambique and the greater Indian Ocean and between Mozambique and the Atlantic. There has been close focus also on Mozambique's role as an indirect supplier of slaves to the Portuguese Indiamen (the Carreira da Índia) that sailed on an annual basis between Goa and Lisbon, and sometimes calling at Mozambique and Brazil. 13

The literature on slaves has focused mainly on those living inland in their own villages under local chiefs or authorities, whether of African, Portuguese or some other descent, while writing on slave trading has been devoted essentially to the sale of slaves to the international markets of the Indian and the Atlantic Oceans. In most cases slaves living under the rule of the urban

\footnotetext{
${ }^{10}$ The Prazos da Coroa Prazos were farms similar to medieval manors in how they were run and in the types of relationships established between landowners and peasants. As Malyn Newitt explains, "It is not easy to say in simple terms exactly what a prazo was (...). To the Portuguese [authorities] they were land grants held under Roman Law contracts of emphyteusis, but from the African point of view they were essentially chieftaincies and as such part of a complex system of social and economic relations bounding together all the people in the region." Malyn Newitt, A history of Mozambique (Bloomington, IN: Indiana University Press, 1995), 217. Prazos varied in size, and geographically they were concentrated along the Zambesi river and its tributaries. Usually, the Prazo included an area under the direct administration of the landlord and several attached villages of free and enslaved African populations. Further information on the Prazo system and the prazotenants can be found in: Isaacman, Mozambique: The Africanication of a European Institution; Malyn Newitt, Portuguese settlement on the Zambesi: exploration, land tenure and colonial rule in East Africa (London: Longman, 1973); Allen Isaacman and Barbara Isaacman, "The prazeiros as transfrontiersmen: a study in social and cultural change," The International Journal of African Historical Studies 8.1 (1975), 1-39; and Rodrigues,

Portugueses e Africanos nos Rios de Sena.

${ }^{11}$ On the different categories of slaves and their roles, see among other studies, Allen Isaacman and Barbara Isaacman, "Slavery and social stratification among the Sena of Mozambique: a study of the kaporo system," in S. Miers and I. Kopytoff, eds., Slavery in Africa: Historical and Anthropological Perspectives (Madison, Wisc.: The University of Wisconsin Press, 1977), 105-120. Allen Isaacman and Barbara Isaacman, Slavery and beyond: the making of men and Chikunda ethnic identities in the unstable world of southcentral Africa, 1750-1920 (Portsmouth, NH: Heinemann, 2004).

${ }^{12}$ On the distinction between "open" and "closed" slavery systems in the IOW, Asia and Africa, see: James L. Watson, Asian and African Systems of Slavery (Berkeley: University of California Press, 1980), and also the discussion of the literature in the Introduction to this volume.

${ }^{13}$ José Capela, O tráfico de escravos nos portos de Moçambique, 1733-1904 (Porto: Edições Afrontamento, 2002); José Capela, "Slave Trade Networks in Eighteenth-Century Mozambique" in David Richardson and Filipa Ribeiro da Silva, eds., Networks and TransCultural Exchange: Slave Trading in the South Atlantic, 1590-1867 (Leiden/Boston: Brill, 2014), 165-194; Pedro Machado, "A Forgotten Corner of the Indian Ocean: Gujarati Merchants, Portuguese India and the Mozambique Slave-Trade, c.1730-1830," Slavery \& Abolition 24.2 (2003), 17-32. Pedro Machado, Ocean Trade: South Asian merchants, Africa and the Indian Ocean, c. 1750-1850 (Cambridge: Cambridge University Press 2014).
} 
colonial elites of nineteenth-century Mozambique are too little studied. As a consequence, and unlike for other regions of both East and West Africa such as Mauritius or Ghana, for example, much less is known about the slave population who lived and worked in some of the main urban centers of Mozambique and their surroundings. We therefore know relatively little about how the forms of slavery there differed - if they did - from the forms of slavery brought about by the emergence of the trans-Atlantic, Indian Ocean and Indian-Atlantic slave trades. ${ }^{14}$ Also, little is known about how the multiple forms of slavery in these spaces coexisted, nor about how urban slavery and other forms of dependency coexisted. In short therefore, no comprehensive study has been done of the enslaved population, the dependent populations, and their masters and patrons living in main urban spaces in the region around Mozambique, nor of patterns of slave-ownership among urban elites in the region.

\footnotetext{
${ }^{14}$ Richard Allen, Slaves, Freedmen and Indentured Labourers in Colonial Mauritius (Cambridge: Cambridge University Press, 1999) provides details on the composition of households, including professions, assets, and slave-ownership, in Port Louis, Mauritius, 90-92, 94-96, 98. Sandra E. Greene, Slave owners of West Africa: decision making in the Age of Abolition (Ghana, $19^{\text {th }}$ century) (Bloomington, Ind.: Indiana University Press, 2017).
} 
Illustration 2: First known population count for the Island of Mozambique, 1820 (first page as way of example)

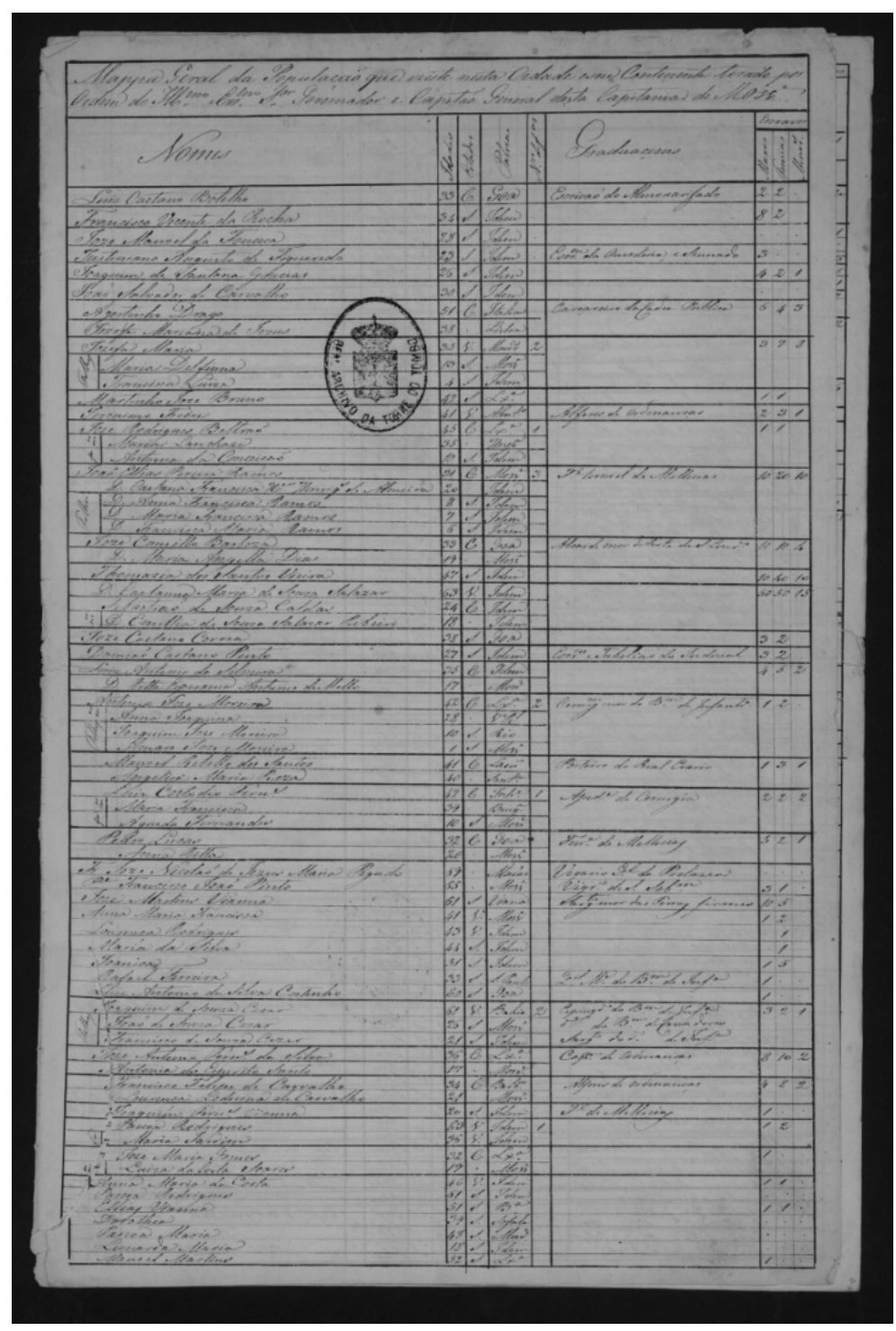

Source: Arquivo Nacional da Torre do Tombo (hereafter ANTT), Ministério do Reino. Partial copies of this document are in the collection of Conselho Ultramarino Mozambique in the Portuguese Overseas Archives (Arquivo Histório Ultramarino, hereafter $A H U)$, located in Lisbon.

However, reference to the type of household surveys cited earlier in this study in combination with the nominal population counts produced by representatives of the Portuguese Crown in early nineteenth century 
Mozambique will allow us to study the slave population that was dependent of urban colonial elites. We shall be able to broaden our understanding both of differences and similarities between local forms of slavery and dependence, and how they might have been connected to the global forms of slavery that were directly linked to the Indian Ocean and the trans-Atlantic slave trade, and to the slave trade that connected those two Oceans. Simultaneously, it will also allow us to look into the profile of the slave masters living in the urban spaces as well as their patron ties to other dependent workers.

For this specific study I have analyzed the enslaved and dependent population who lived in three of the main towns of nineteenth-century Mozambique. Those towns are Tete, Inhambane and Mozambique Island ${ }^{15}$ and their respective outskirts. ${ }^{16}$ To this purpose, I used the population counts and related household surveys produced by clergymen, the civil and military administrators at the request of the Portuguese Crown in 1820 and 1822 for the Island of Mozambique, Inhambane, and Tete (see Illustrations 1 and 2). ${ }^{17}$ The main goals of this study are, therefore, to trace the profile of those slave populations, identify their origins, where they lived and what they did; and explain how they came to be dependent on the colonial urban elites in

\footnotetext{
${ }^{15}$ During the same period, Quelimane and Sena were also important urban centers that contained populations larger than Inhambane. However, despite all research efforts, I have not yet discovered population counts for them that are comparable to those for the island of Mozambique, Tete and Inhambane under examination here. For that reason I have decided not to include either of them in this study.

${ }^{16}$ The population counts under analysis in this study include not only people living in the urban centers, but also in the surrounding areas, where the main land and labor holders kept their properties (often prazos of the Portuguese Crown) and their slaves. In the case of the island of Mozambique, the surrounding areas very likely included Mossuril and Cabeceiras, and in Tete the prazos outside the town.

${ }^{17}$ The first population counts with nominal data at household level were produced in the early 1800 s, but only two have survived, one for Tete and the other for Inhambane. So far, no population count has been found for the island of Mozambique, the biggest town under Portuguese control at the time. In light of that and also of the quality of the data in the two aforementioned tables, the PI of the Counting Colonial Population Project, Paulo Teodoro de Matos, and I agreed that the set of maps produced in the 1820 s was more suitable for comparative purposes given their wider geographical and population coverage and the higher quality of their data. The following are the source materials used in this study: Tete (1822): Mappa da População da Villa de Tete e seu Termo, como nelle se declara, 1 March 1822. AHU, Moçambique: cx. 183, doc. 89; Mozambique Island (1820): Mappa Geral da População que eziste nesta Cidade e seu Continente tirado por Ordem do Ilustríssimo Excelentíssimo Senhor Governador e Capito Geral desta Capitania de Mossambique, 5 December 1820, Portuguese National Archive/Torre do Tombo (hereafter AN/TT): Ministério do Reino; Mappa Geral dos Banianes que existem nesta Cidade tirado por ordem do Illustrissimo e Excelentissimo Senhor Governador e Capitão General desta Capitania de Mossambique, 5 December 1820, AN/TT: Ministério do Reino; Mappa Geral dos Mouros que existem nesta Cidade tirado por ordem do Illustrissimo e Excelentissmo Senhor Governador e Capitão General desta Capitania de Mossambique, 5 December 1820, AN/TT: Ministério do Reino; Inhambane (1820): Mappa Georgraffico, Arthmetittico e pullitico da Cappitania de Inhambane, que da o Governador Izidro Manoel de Carrazedo, ao Illmo. E Exmo. Senhor Governador e Capitão General deste Estado, 1 July 1820, AHU, Moçambique, cx. 170, doc. 2.
} 
Mozambique. For their part, those elites were variously Portuguese, Banyan/Indian or Swahili, the Swahili being Muslims which often led the Portuguese to refer to them as Mouros, i.e. "Moors". It should therefore be possible to determine the dominant patterns of slave-ownership among those three main population groups, and to discuss how different those forms of slavery were from the ones found in other locations around the Indian Ocean or in the Americas - or indeed similar to them. It should indeed be obvious if the circumstances of what we might think of as "local" slavery around Mozambique differed from those of the sort of slavery which emerged with the rise of the plantation system and the consequent development of the early modern trans-Atlantic and Indian Ocean slave trade.

\section{Early nineteenth-century Mozambique: Portuguese rule, economy and local forms of dependence and slavery}

By the early 1800s Mozambique Island, Inhambane and Tete were three of the main urban centers in the territory that had fallen under the influence of the Portuguese Crown and its subjects. In fact, for most of the eighteenth and nineteenth centuries the Portuguese presence in the region, whether officials of the Portuguese Crown and the Catholic Church or private individuals was mainly limited to various coastal trading posts and a few settlements in the Zambezi Valley region. They began on the coast between Sofala and Quelimane and stretched into the heartlands, reaching as far as Sena, Tete and Zumbo. During the course of the century Portugal also came to control a number of coastal areas, including the Quirimbas Islands, Ibo, Angoche, Inhambane and present-day Maputo, which before independence was known as Lourenço Marques. During that period, Portuguese influence therefore extended as far as the present-day borders with Zambia, Malawi and Zimbabwe (see Map 1). However, the remaining territory of Mozambique remained under the control of the local African authorities and consequently stayed out of the reach of the representatives either of the Portuguese Crown or the Catholic Church. 
Map 1: Mozambican territory controlled by the Portuguese, $17^{\text {th }}-19^{\text {th }}$ centuries

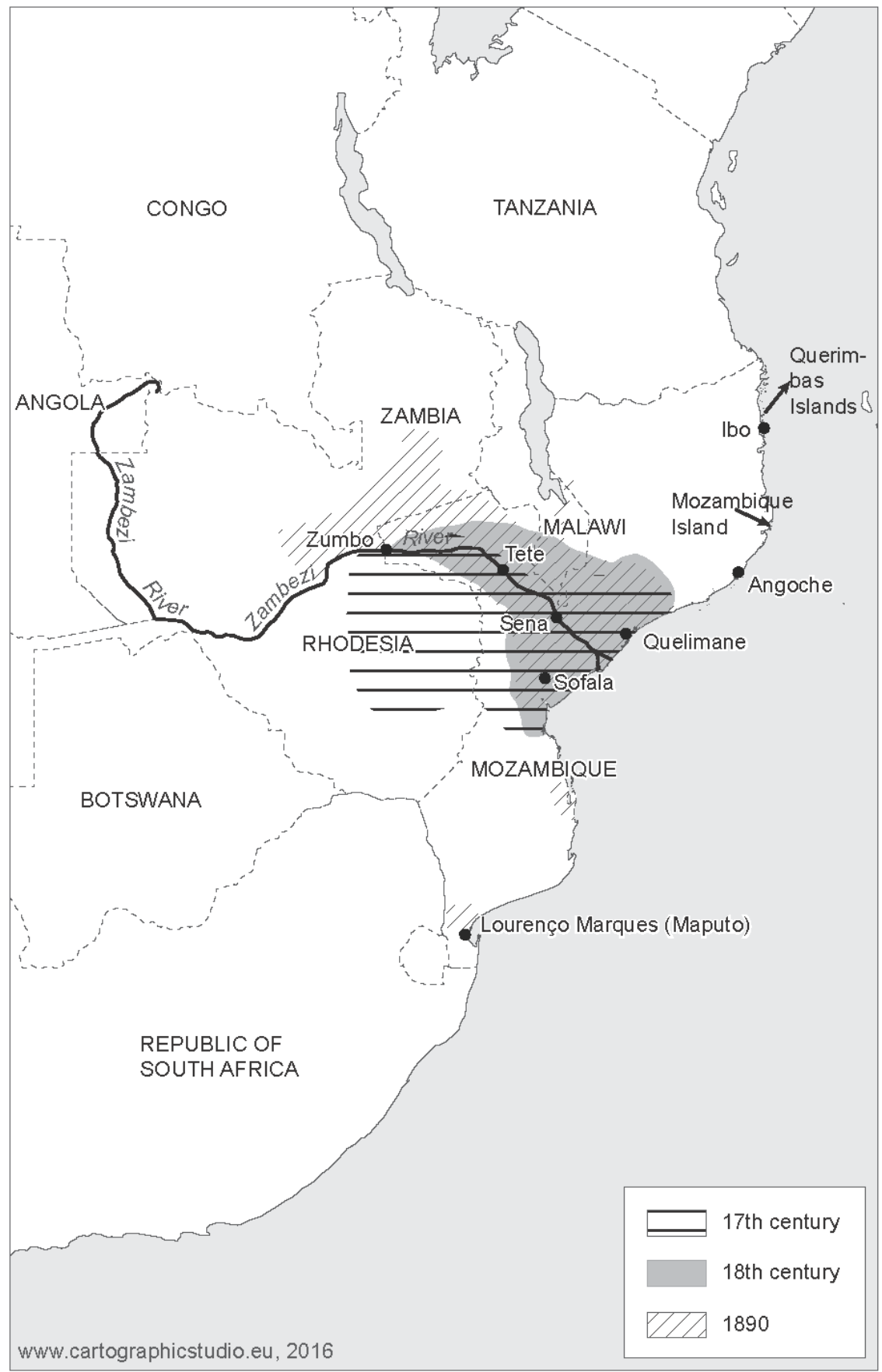


Within the territory controlled by Portugal the free populations of Portuguese, Indian and Swahili origin represented a small fraction of the inhabitants. Many individuals combined different activities which might include the tenancy and management of Prazos in the Zambezi Valley. The Prazos da Coroa was a system of land tenure regulated on the same principles as the Roman legal contract called emphyteusis and was put in place by the Portuguese Crown from the seventeenth century onwards with the idea of attracting settlers to the Zambezi Valley. ${ }^{18}$ From an economic point of view the prazos were similar to medieval manors both in how they were run and in the types of relationship established between tenants and dependent peasants. That in turn implies that Prazo tenants acted as landlords and those who lived within their areas of influence were their dependents, regardless of whether they were enslaved or not. In that way Prazo tenants might be the employers of enslaved or of non-enslaved African dependent workers (colonos or colonos forros as mentioned earlier), establishing with enslaved and nonenslaved workers a relationship closer to client-patron than to slave-master as more commonly found in the Americas. These type of clientele and patronage relationships resemble others found in other regions of the IOW as earlier studies have illustrated and several contributions in this volume also do.

The free population of Portuguese, Indian and Swahili origin combined military and/or administrative service to the Portuguese Crown with trade in various products or commodities and enslaved Africans. Many of the free residents of nineteenth century Mozambican towns were engaged in the coastal trade that connected the island of Mozambique with the ports of Quelimane, Sofala, Inhambane, Cape Delgado and the Cape of Correntes and the Quirimbas Islands, as well as the trade routes that connected the Mozambican coast to the Indian sub-continent and other ports in the Greater Indian Ocean.

The Mozambican coastal trade circuits brought many slaves to the island of Mozambique, the vast majority of whom would be sold onto the international slave markets of the Indian and Atlantic Oceans -so-called 'slaves for sale or export'. However, a limited number were acquired by the colonial elites who lived in the main towns of Mozambique. Those slaves were destined for two main purposes: domestic service and the so-called "slaves for hire". ${ }^{19}$ Alongside these two types of slaves, Crown's slaves were

\footnotetext{
${ }^{18}$ Under Roman Law, emphyteusis was a contract under which a landed estate was leased to a tenant, either in perpetuity or for many years, upon payment of an annual rent or canon, and on condition that the lessee should improve the property, by building, cultivation or otherwise, with the lessee having the right to alienate the estate at his pleasure or pass it to his heirs by descent, and with the property being free from any right of revocation, re-entry, or claim of forfeiture on the part of the grantor, except for nonpayment of the rent. The right granted by such a contract was designated jus emphytcuticum, or emphytcuticarium.
}

${ }^{19}$ Capela, "Slave Trade Networks in Eighteenth-century Mozambique," 186-ss 
also commonly found in the main towns where royal officials and royal administrative and military institutions were present.

In principle, "slaves for sale" were acquired in the interior by the Makua people who controlled the trade in the regions that fell outside the jurisdiction of local African chiefs and Prazo tenants. Slaves were brought to the coastal towns from the interior in caravans, along with commodities like elephant tusks, gold, and other trade items. "20 "Slaves for sale" and "slaves for hire" were therefore a constant presence in the Portuguese cities and fortresses along the coast, as well as in vessels of the Portuguese fleets sailing the Indian Ocean - the Carreira da Índia or, "Portuguese Indiamen". The slaves were in transit either as "slaves for sale" or often as workers - "slaves for hire". The "slaves for hire" performed a variety of tasks associated with local daily life, including domestic service, street selling, and craftwork. Together they were part of the early modern forms of slavery that emerged with the rise of the global slave trade circuits that connected the Atlantic, Indian and Pacific Oceans. They formed a group quite distinct from the slaves who lived and worked in villages near towns and as dependents of the Portuguese-descended Prazos' tenants or the local African chieftains and whose enslaved condition was directly linked to local forms of slavery and dependence.

The largest group of slaves in the region were the locally enslaved Africans. Many of them had been attached to plots of land and their tenants through a "system of reciprocal obligations" so that the relationship between master and slave approached more closely that of feudal patronage and dependence than the forms of slavery that emerged in the Americas and in other locations around the Indian Ocean. In most cases, slaves had families and lived in their own villages which fell under the jurisdiction of the Portuguese Prazos or, in territories outside the Portuguese sphere of influence, and under the rule of the local chiefs and authorities. Slaves often performed a number of different tasks for Prazo tenants and local chiefs, alongside activities like hunting, fishing, and foraging for their own subsistence. As time went on slaves of that type became known as Chicunda and were employed by their masters to collect taxes from non-enslaved African dependents - the so-called colonos or colonos forros as mentioned earlier. The colonos too lived and worked in independent villages but in the spheres of influence of prazo tenants or African chiefs. The Chicunda were even employed on diplomatic missions on behalf of Prazo tenants and local African chiefs, as well as in the defense of the Prazos and chieftaincies and dependent areas, and also in trade. In fact the Chicunda, or Achicunda, comprised most of the slaves at that time. This situation illustrates well not only the coexistence of enslaved people and other dependents. Additionally, this reality makes clear the role played by function and context in determining slave social and economic status, and it also shows the type of ties that linked them and their masters as well as dependents and their patrons.

${ }^{20}$ Overtime this situation would change due to the growing demand for slaves. 
The remaining slaves lived as dependents of the Prazos and some of them lived actually in them. They had a wide variety of roles. In the first half o the eighteenth century, for example, the "Jesuit prazos employed cooks, bakers, barbers, tailors, washerwomen, masons, fishermen, seamstresses, carpenters, tillers, ironsmiths, boat-builders and gold miners as well as household and garden slaves". ${ }^{21}$ A significant proportion of the activities developed by slaves in rural areas was directed towards the production of foodstuffs for local consumption and goods for the market economy, with any revenues accruing going to the slaves' owners and masters. There were, however, certain distinctions in the types of work done by male and female slaves, with most female slaves occupied in agriculture and mining. In the aforementioned Jesuit Prazos, for example, these two activities occupied more than $85 \%$ of the female slave workforce. ${ }^{22}$

The non-enslaved African dependents - colonos forros - constituted the majority of the population both in and outside the areas controlled by or under the influence of the Portuguese Crown and the Prazos da Coroa which were located along the Zambezi Valley and held by families of Portuguese descent. As Allen Isaacman and Malyn Newitt explained, they were "essentially chieftaincies and as such part of a complex system of social and economic relations bounding together all the people in the region." ${ }^{23}$ That implies that even though the colonos were not formally enslaved they lived and worked as dependents of the tenants of the Prazos' as well as of the local chiefs and their living and working conditions did not differ much from slaves. This evidence makes clear that freedom was not a key element to tell apart enslaved and non-enslaved dependents in this region, with function and context playing a crucial role in determining their status as the debate on slavery in the IOW has been demonstrating for other regions. ${ }^{24}$

Alongside their work in the Prazos the colonos were engaged in five main activities. Those were gold extraction in surface-mine workings in the Central African heartlands; hunting of elephants for both their meat and ivory; foraging for honey, wax, and wood; as well as the transport of agricultural surplus, ivory, gold, foraged goods, and enslaved Africans to important inland ${ }^{25}$ and coastal trading centers, such as Tete, the Island of Mozambique,

\footnotetext{
${ }^{21}$ Newitt, $A$ history of Mozambique, 241.

${ }^{22}$ Newitt, $A$ history of Mozambique, 241.

${ }^{23}$ Newitt, $A$ History of Mozambique, 217. Each Prazo varied in size, but usually included an area under the direct administration of the land tenant and attached villages of free and enslaved Africans. Isaacman, Mozambique: The Africanization of a European Institution. Newitt, Portuguese Settlement on the Zambesi. Isaacman and Isaacman, "The Prazeros as Transfrontiersmen."

${ }^{24}$ See among many others, for example, Anthony Reid, Slavery, Bondage and Dependency in Southeast Asia (St. Lucia: University of Queensland, 1983). Martin A. Klein, ed., Breaking the Chains. Slavery, bondage and Emancipation in Modern Africa and Asia (Madison: Wisconsin: University of Wisconsin Press, 1993).

${ }^{25}$ Newitt, A History of Mozambique, 194.
} 
Inhambane, and Quelimane. ${ }^{26}$ Alongside those activities the colonos engaged in subsistence agriculture including the production of maize, millet, wheat, sugar, tobacco, and groundnuts and groundnut oil. As already mentioned, the inland slave trade was controlled mainly by the Makua people whereas elephant hunting was dominated by the Maravi, the Lunda, and the Bisa. Meanwhile the caravan trade between the interior and the coast was led by the Yao people. ${ }^{27}$ In all communities agriculture was mainly women's work, with male seasonal participation only to help clear the fields and during harvesting. ${ }^{28}$

Part of the gold, ivory, honey, wax, and agricultural production ended up in the hands of the local authorities, either African or Portuguese, in the form of tribute, as the anecdote in the introduction of this study clearly illustrates. ${ }^{29}$ Tribute labor was often also demanded by African village and community chiefs as well as by Prazo tenants of Portuguese descent, in exchange for protection.

The work and products paid as tribute to Prazo tenants and African chiefs were not only for domestic consumption, but also to supply small urban centers, to provision ships, and for export through the coastal ports. The products obtained through farming, hunting, fishing, and foraging also fed villages and non-enslaved Africans and their families. The colonos therefore had a twofold relationship of dependence to the Prazo tenants, in that they were obliged to work the land for the Prazo tenant, and were required to pay a tribute in kind which was mainly directed to supply the market economy. It is likely that identical relations existed between non-enslaved African dependents and local African chiefs, as the seminal works by Newitt and Isaacman on the Prazo system have suggested.

Thus, in the early nineteenth-century Mozambican territory controlled by the Portuguese, and probably also in the areas under the rule of local African chieftaincies, different forms of slavery and dependency seem to have coexisted in both rural and urban areas, and the relationship between enslaved and non-enslaved with the most powerful land-tenants dominated by clientele and patronage, through which protection is paid in kind and work, allowing local elites to control labor and production.

\footnotetext{
${ }^{26}$ Inland trading centres were called feiras in Portuguese sources.

${ }^{27}$ Newitt, A History of Mozambique, 183. On the Mozambican slave trade and its inland and overseas dimensions, see, among others, Edward A. Alpers, Ivory and Slaves: Changing Patterns of International Trade in East Central Africa to the Later Nineteenth Century (Berkeley, 1975), Pedro Machado, "A Forgotten Corner of the Indian Ocean: Gujarati Merchants, Portuguese India and the Mozambique Slave-Trade, c.1730-1830", Slavery \& Abolition, 24:2 (2003), 17-32; Capela, "Slave Trade Networks in EighteenthCentury Mozambique", 165-194.

${ }^{28}$ Kathleen E. Sheldon, Pounders of Grain: A History of Women, Work, and Politics in Mozambique (Portsmouth, NH, 2002), ch. 1.

${ }^{29}$ Newitt, A History of Mozambique, 237-242.
} 


\section{Forms of Slavery and patterns of slave ownership in main Mozambican urban centers and their outskirts, c. $1800^{30}$}

Who then were the slaves whom we find in the demographic sources of the early nineteenth century Mozambique as the registered property of the urban colonial elites? How many of them were there? How many of them were men and how many women? Where did they come from? How did they come to be dependent on the urban elites to the extent that they were owned by them? Where did they live? What did they do? Who were their masters? Were there different preferences in terms acquisition and ownership of slaves among masters from the different urban elite groups? And if so, why?

To answer those questions I analyzed 398 households selected from Mozambique Island (289), Inhambane (66) and Tete (43). ${ }^{31}$ According to the available population counts, those three towns were home to 10,203 individuals, with the island of Mozambique being the biggest urban center in the territory, with a total of 4,671 residents. Then came Tete with 4,577 inhabitants and Inhambane with 955. In each of the three towns the majority of the individuals registered were slaves, with 4,423 in Tete, 4,149 in the island of Mozambique and 765 in Inhambane. The free population accounted for just a small fraction of the total population, at $20 \%$ in Inhambane; approximately $12 \%$ in the island of Mozambique and fewer than $5 \%$ in Tete (see Graph 1). Those results show us three urban centers with economies which appear to have relied heavily on slave labor. Non-enslaved African dependents, in contrast, were mainly absent in these counts. Only in the town of Tete they appeared registered, but in a small number accounting for less than $10 \%$ of the town's population. This evidence suggests that free dependent African workers were more present in the non-urban spaces. This is confirmed by the information about their villages in the real estate surveys and household bulletins carried out in the outskirts of towns and other areas further inland, in particular, along the Zambezi Valley.

\footnotetext{
${ }^{30}$ Part of the data presented and discussed in this section of the study was used to study the population structures and household composition in the 1820s of the three Mozambican towns referred to in the analysis. The results of that research were published in the following article: Filipa Ribeiro da Silva, "Counting People and Homes in Urban Mozambique in the 1820s: Population Structures and Household Size and Composition," African Economic History 45:1 (2017): 46-76.

${ }^{31}$ Although small and with low population densities, these towns were the main urban centers of the territory controlled by the Portuguese in the $1750 \mathrm{~s}-1800 \mathrm{~s}$.
} 
Graph 1

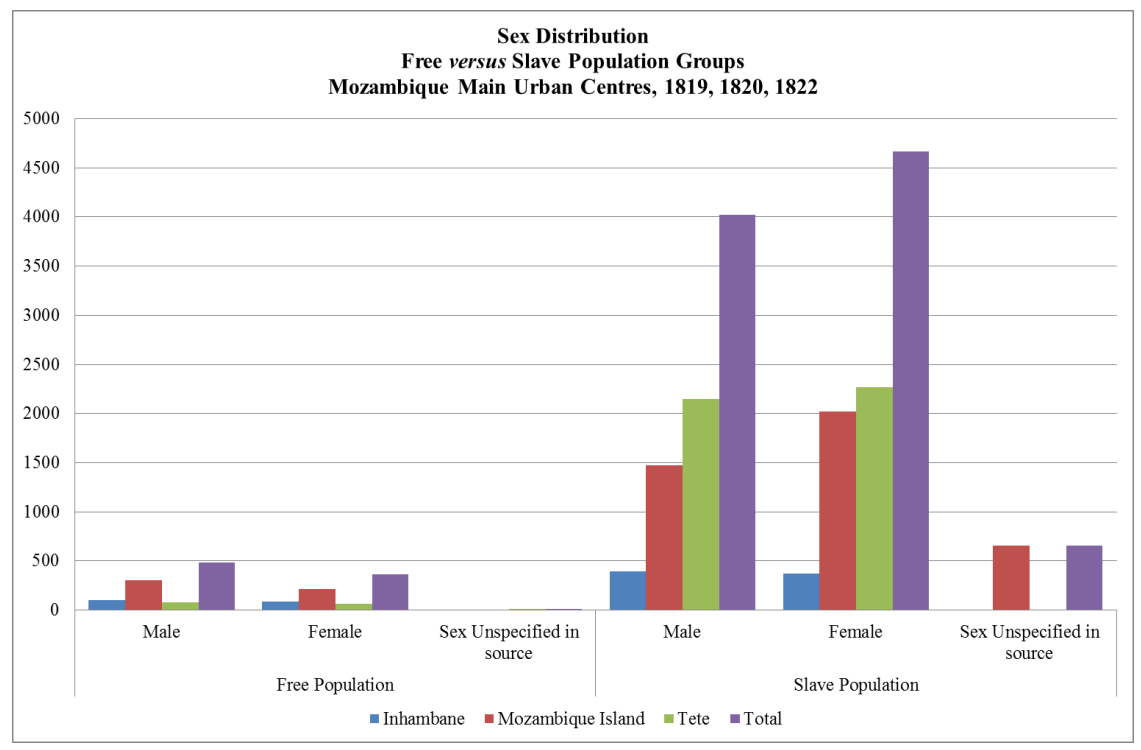

Sources:

Tete (1822): Mappa da População da Villa de Tete e seu Termo, como nelle se declara, 1 March 1822. Portuguese Overseas Historical Archive (hereafter AHU): Moçambique: cx. 183, doc. 89;

Mozambique Island (1820): Mappa Geral da População que eziste nesta Cidade e seu Continente tirado por Ordem do llustríssimo Excelentíssimo Senhor Governador e Capito Geral desta Capitania de Mossambique, 5 December 1820, Portuguese National Archive/Torre do Tombo (hereafter AN/TT): Ministério do Reino; Mappa Geral dos Banianes que existem nesta Cidade tirado por ordem do Illustrissimo e Excelentissimo Senhor Governador e Capitão General desta Capitania de Mossambique, 5 December 1820, AN/TT: Ministério do Reino; Mappa Geral dos Mouros que existem nesta Cidade tirado por ordem do Illustrissimo e Excelentissmo Senhor Governador e Capitão General desta Capitania de Mossambique, 5 December 1820, AN/TT: Ministério do Reino;

Inhambane (1820): Mappa Georgraffico, Arthmetittico e pullitico da Cappitania de Inhambane, que da o Governador Izidro Manoel de Carrazedo, ao IIImo. E Exmo. Senhor Governador e Capitão General deste Estado, 1 July 1820, AHU, Moçambique, cx. 170, doc. 2.

Notes:

*Includes population of Portuguese descent and the so-called "Mouros" (Moors);

\# Includes population of Portuguese descent, the Banyan Population and the so-called "Mouros" (Moors);

** Includes population of Portuguese descent. No information concerning other population groups.

In the towns, most of the slaves were adult women (see Graphs 1 and 2). They accounted for the majority of the slave population registered in Mozambique 
Island and Tete. Only in Inhambane were there more adult male slaves (see Graph 1). The pattern was similar in other port-towns in Atlantic Africa, such as for example of nineteenth-century Benguela (Angola), as well as in other regions of the IOW. ${ }^{32}$ By contrast, young or child slaves rarely appear in the registers, and that is largely because the purpose of the registration of the slave population was to account for property and its value. Adult slaves were of greater economic value than child or even simply young slaves. Moreover adults, and in particular men, could be used for military purposes, which might be why more adult men were registered in certain towns.

Graph 2

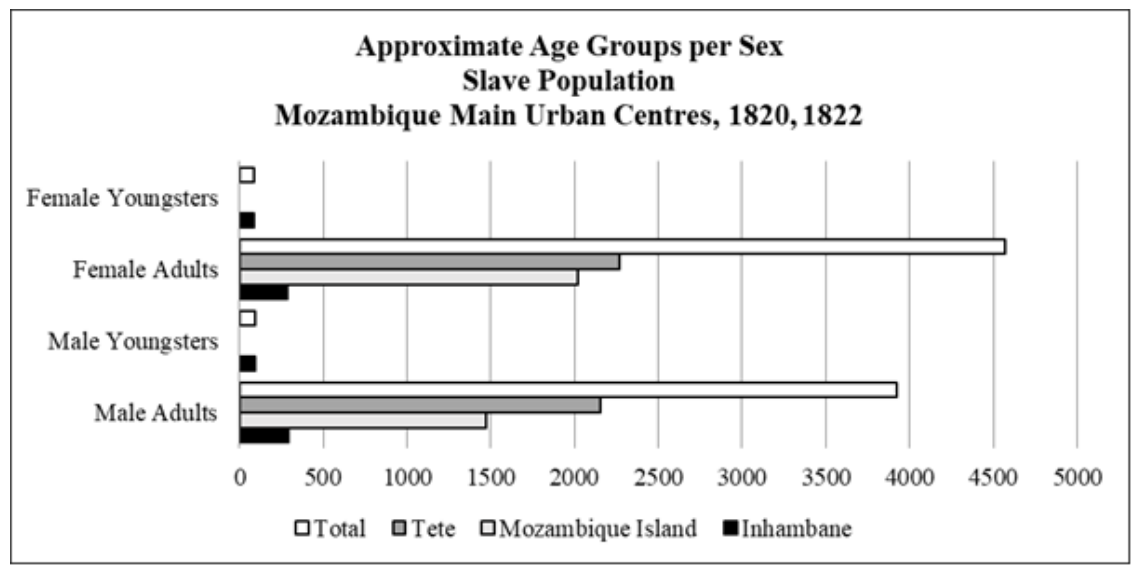

Sources: see legend to Graph 1.

As for the geographic origins of the registered slave population, the demographic sources under scrutiny here tell us little. However, it is probable that they were from the territory of Mozambique or its neighboring areas, as they are referred to as Negros, negras, Muleques and Negrinhas which implies they were of dark complexion and so likely of African origin. Of interest is that two different types of slaves were registered in the sources under analysis. There were "urban slaves" who lived inside the towns, many of them actually in the households of their masters. These urban slaves were employed as domestic workers and as slaves for hire. The other category of slaves were those who lived in the surrounding areas of the towns, on the estates belonging to the free urban residents.

\footnotetext{
${ }^{32}$ Mariana P. Candido, Fronteras de Esclavization: Esclavitud, Comercio e Identidad en Benguela, 1780-1850 (Mexico City: El Colégio de México, Centro de Estudios de Asia y Africa, 2011), 90-92. Indrani Chatterjee and Richard M. Eaton, eds., Slavery and South Asian History 1526-1707 (Dehli, Oxford: Oxford University Press, 2000). Gwyn Campbell, ed., The Structure of Slavery in the Indian Ocean Africa and Asia (London: Frank Cass, 2004).
} 
The majority of the households examined owned fewer than 5 slaves. That was the dominant pattern in Mozambique Island and quite common in Inhambane also (see Graph 3). Ownership of such small numbers of slaves suggests that their masters would either keep them within the household to perform domestic chores or would hold them as slaves for hire, offering their services and skills to prospective customers in exchange for payment. In doing that the owners therefore transformed the slave into a source of income. A similar practice was common in Lisbon also, as it was in other colonial cities throughout the Portuguese Empire - and in cities in other Europeanheld colonies, for that matter. ${ }^{33}$

This evidence suggests that many of the slaves in question were acquired in the towns' slave markets, where slaves arrived either via the inland or along the Mozambican coast. I would therefore argue that the majority of the households examined in the Mozambican towns likely acquired their domestic service and slaves for hire through the same channels as those that catered to the international slave markets of the Indian and Atlantic Oceans. Consequently, the slaves acquired by and living in local households were in many ways just as much part of the global slave trade circuit and represented a more modern form of slavery that emerged with the rise of the international slave trade. They were comparable to slaves acquired in, living in and working in other port-cities within the Indian and Atlantic Ocean areas. This situation contrasted with the households owing tens and hundreds of enslaved people and having multiple non-enslaved dependents, as I will explain next.

Unfortunately, the demographic sources under scrutiny here are silent about the types of activity performed by the slaves in Mozambican towns. However, given that those towns played important roles as ports, whether as sea-ports in the cases of Inhambane or the island of Mozambique, or as riverports like Tete, slaves were likely to have done harbor-related work such as ship repairs, as well as working as street vendors, washer men and -women, and so on, just as they did in other port-cities of the former Portuguese empire, like Bahia. There, activities done by slaves at about the same time have been depicted in drawings and paintings by artists of the time, such as Rugendas and Debret. Slaves were also an important source of labor for the Portuguese Crown and her representatives and institutions in these towns.

\footnotetext{
${ }^{33}$ As way of example, see the following studies: Jorge da Fonseca, Escravos e Senhores na Lisboa Quinhentista (Lisboa: Edições Colibri, 2010). A.J.M. Barros, "O Porto e o Trato de Escravos no século XVI," Africana Studia 7 (2004): 31-51. D. Lahon, "O escravo africano na vida económica e social portuguesa do Antigo Regime," Africana Studia 7 (2004): 73-100. F. Araújo and, S. Alves, "A comunidade escrava de Leça da Palmeira seiscentista, Revista da Faculdade de Letras da Universidade do Porto - História", 3rd series, 5 (2004): 193-210. M.H.M. Mesquita, "Escravos em Angra no século XVII: uma abordagem a partir dos registos paroquiais, Arquipélago - História, 2nd series, 9 (2005): 209-230. M. DO R. Pimentel, Viagem ao fundo das Consciencias. A escravatura na época Moderna (Lisboa: Bertrand, 1995). A. C. DE C. M. Saunders, A Social History of Black Slaves and Freedmen in Portugal, 1441-1555 (Cambridge: Cambridge University Press, 1982).
} 
Graph 3

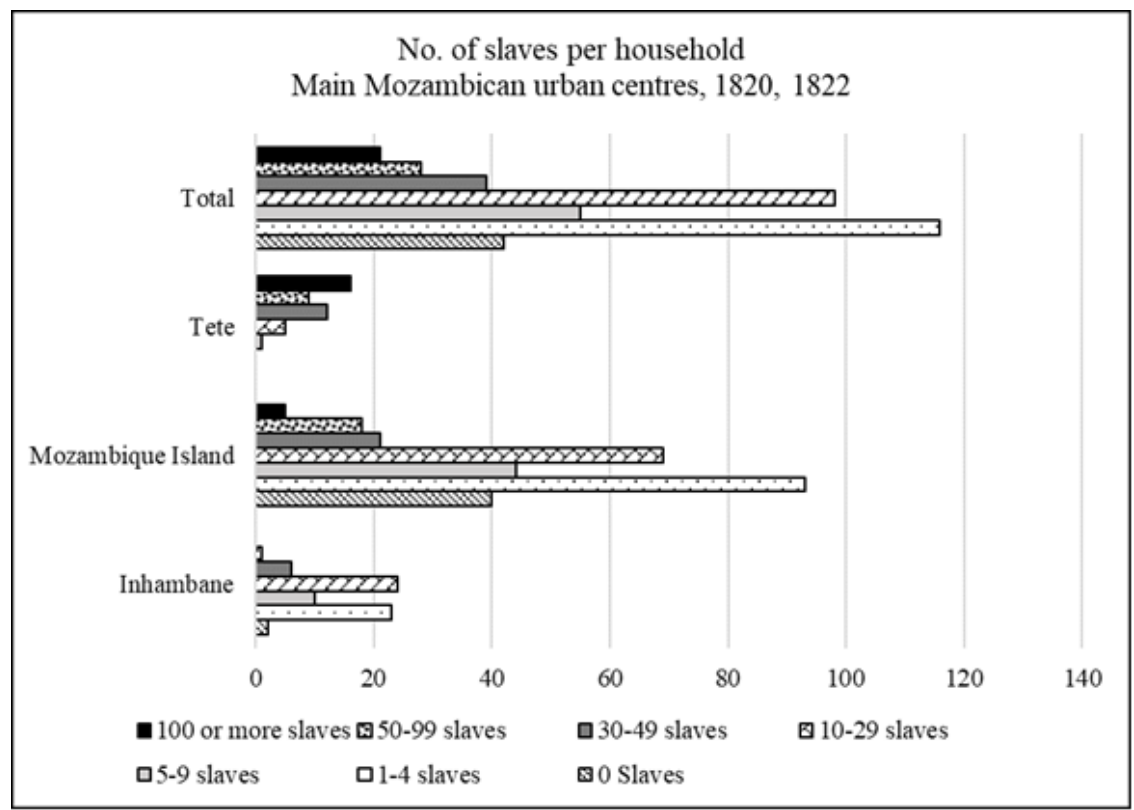

Sources: see legend to Graph 1.

In the three Mozambican urban centers under analysis here there were also a considerable number of households that owned between 10 and 29 slaves or even more. Owning higher numbers of slaves, especially more than 30 , appears to have been more common in Tete than in any of the other towns, where it was found that most households owned 100 slaves or more, or at any rate more than 30 (see Graph 3). Such households acquired their larger numbers of slaves in a rather different way than applied to the domestic slaves and slaves for hire just mentioned. The larger groups of slaves were almost always acquired together with property and tenancy rights over land - socalled Butaca - granted by the Portuguese Crown, through the Prazos system. Butaca encompassed the transfer and appropriation both of assets and people attached to the land and the right of the tenant to exercise power over the them. ${ }^{34}$ Butaca was usually granted together with an emphyteusis contract that regulated the Prazo tenancy of Crown land. Many such slaves had been attached to the land and its tenant through the "system of reciprocal obligations" already mentioned. In this sense, the relationship between master and slave approached more feudal patronage and dependence than the forms of slavery that emerged in the Americas. These relationships and ties of rights

${ }^{34}$ Capela, O Tráfico de Escravos nos Portos de Moçambique, 21. 
and obligations are somewhat identical to those found in other parts of the IOW..$^{35}$

In the households containing a higher number of slaves in Tete therefore, as in those on the island of Mozambique and in Inhambane, the relationship between masters and slaves must have been different from those between domestic slaves and slaves for hire and their masters. Most probably, the more slaves owned the more distant the relationships with masters would have been as a result of naturally more limited personal contact. Different also were the types of activities performed by slaves in households with more slaves. A small number of those slaves worked at domestic tasks within the household but the majority lived outside it on the land they worked for their masters or digging for gold in the surface mining works that still existed, called "bars". That was especially true in the area of Tete, which was close to the mining areas. It is also probable that most slaves based near Tete lived in dedicated villages under the protection of the tenants of the Prazos da Coroa.

Similar patterns of slave holding were observed in households regardless of whether they were headed by men or women. As for all households, 30\% of female-led households owned fewer than 5 slaves, or between 10 and 29 slaves. It must be noted, however, that more than $10 \%$ of female-headed households owned 50-99 slaves, more than 5\% owned 30-49 slaves, and more than 5\% owned more than 100 slaves (see Graph 4).

For all households, higher numbers of slaves were owned by women in Tete, while in Mozambique Island and in Inhambane, most of the households headed by women owned fewer than 5 slaves or between 10 and 29 slaves. The activities performed by slaves owned by households headed by women might have been the same as those described above, although it must be mentioned here that owning slaves for hire was a very common practice among single women and widows for whom it was regarded as a respectable way to obtain income without having to work outside the household, and without doing manual labor, both of which activities many considered unsuitable for decent women.

${ }^{35}$ Campbell, "Servitude and the changing face of demand for labor," 25. 
Graph 4

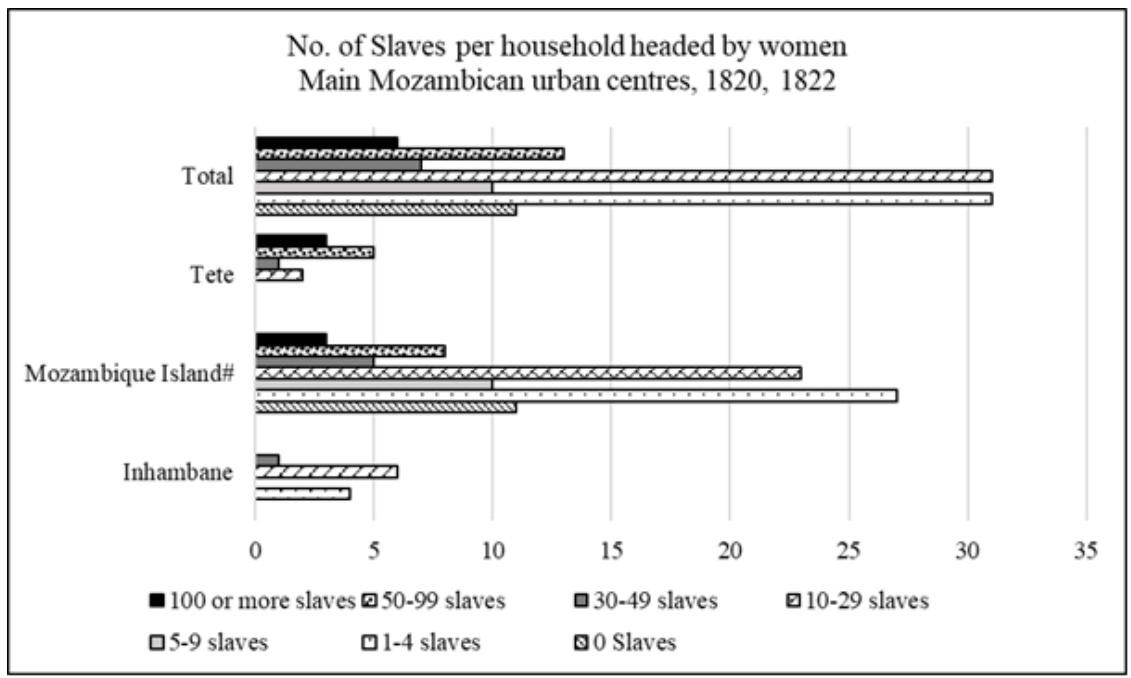

Sources: see legend to Graph 1.

Differences in slave ownership were evident not only in the households in each of the three urban centers under scrutiny here, but among different population groups living in them. That is notably true for Mozambique Island and Inhambane, where Swahili Muslim and Banyan communities lived sideby-side with people of Portuguese descent. ${ }^{36}$ The majority of the free population living in the three urban centers were regarded as being of Portuguese descent (regardless of where they actually originated and most probably regardless too of their skin color) (see Graph 5). The Swahili Muslims were present only in Inhambane and Mozambique Island, accounting for $20 \%$ and $12 \%$ of the free population, respectively (see Graph $5)$. The Banyan merchants from Diu were registered only in Mozambique Island and represented more than $10 \%$ of the free population (see Graph 5). ${ }^{37}$

\footnotetext{
${ }^{36}$ This comparison cannot be made for Tete, as the population tables available for this town registered only inhabitants of Portuguese descent.

${ }^{37}$ For further information on household size and composition in these three urban centres of early nineteenth-century Mozambique, see: Ribeiro da Silva, "Counting People and Homes."
} 
Graph 5

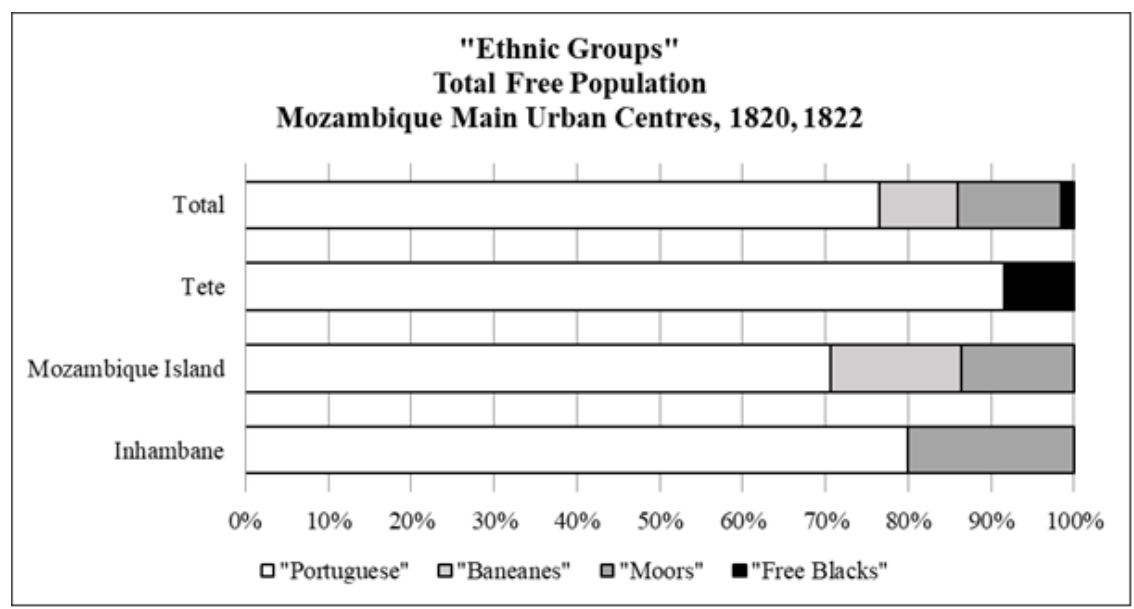

Sources: see legend to Graph 1.

Note: Free Blacks, i.e. Negros Livres as mentioned in the Portuguese sources were nonenslaved Africans. They rarely appear in the population counts under analysis here. This information is available only for Tete, and the number of non-enslaved Africans registered was very low (see Graph 5). Non-enslaved Africans registered in the population counts were likewise accounted as property. In other words, they were regarded as household assets as were slaves.

A detailed analysis of slave holding patterns per household among the three main population groups resident in Mozambique Island shows that approximately $40 \%$ of households headed by people of Portuguese descent owned no slaves. Among the Banyans however, approximately $30 \%$ of households had no slaves, while fewer than $10 \%$ of Muslim households held no slaves (see Graph 6). However, in both Mozambique Island and Inhambane the population of Portuguese descent owned a higher number of slaves than the Muslim population, with 683 as against only 82 (see Graph 7). ${ }^{38}$

There were differences also in gender preferences for slave ownership among the three main groups of slave masters. In Mozambique Island female slaves predominated in Portuguese and Muslim households, while male slaves were more common in Banyan households (see Graph 8). This high number of males might have been related to the commercial and shipping activities developed by the Banyan group, which required strong labor force for heavy duty work, including loading and unloading, and suitable to travel overseas on board their vessels. In the coastal port-town of Inhambane, households of Portuguese descent and of Muslim background alike also

\footnotetext{
${ }^{38} \mathrm{AHU}$, Moçambique, cx. 170, doc. 2: 1820-07-01: "Mappa Georgraffico, Arthmetittico e pullitico da Cappitania de Inhmmambane, que dá o Governador Izidro Manoel de Carrazedo, ao IIImo. E Exmo. Senhor Governador e Captião General deste Estado.”
} 
showed a slight preference for male slaves (see Graph 9) although the difference in actual numbers was small.

\section{Graph 6}

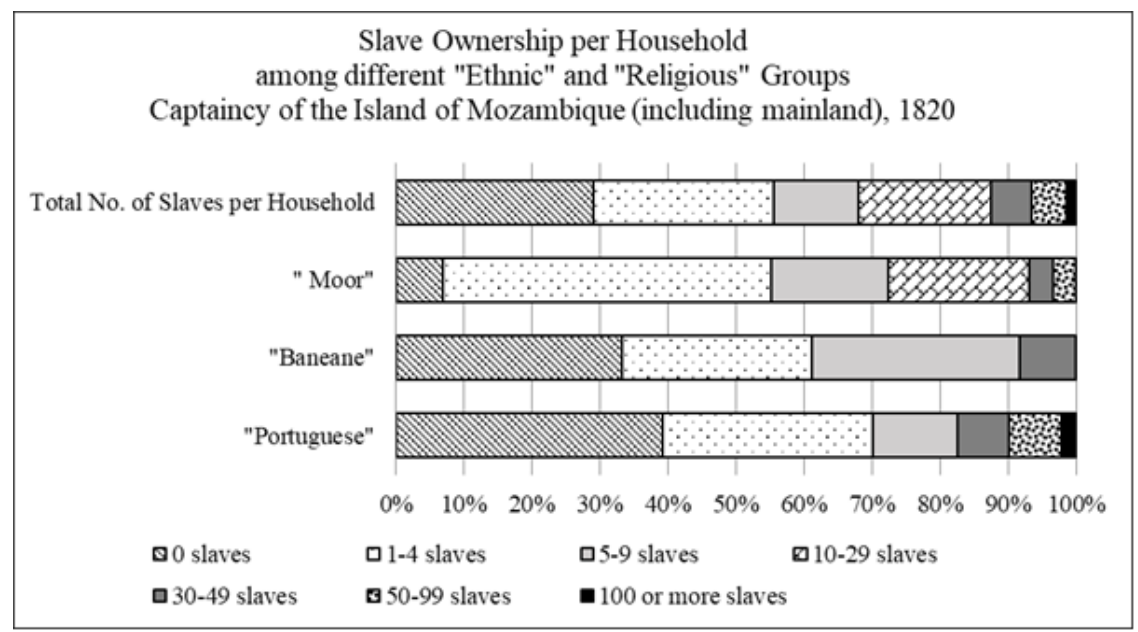

Sources: see legend to Graph 1.

\section{Graph 7}

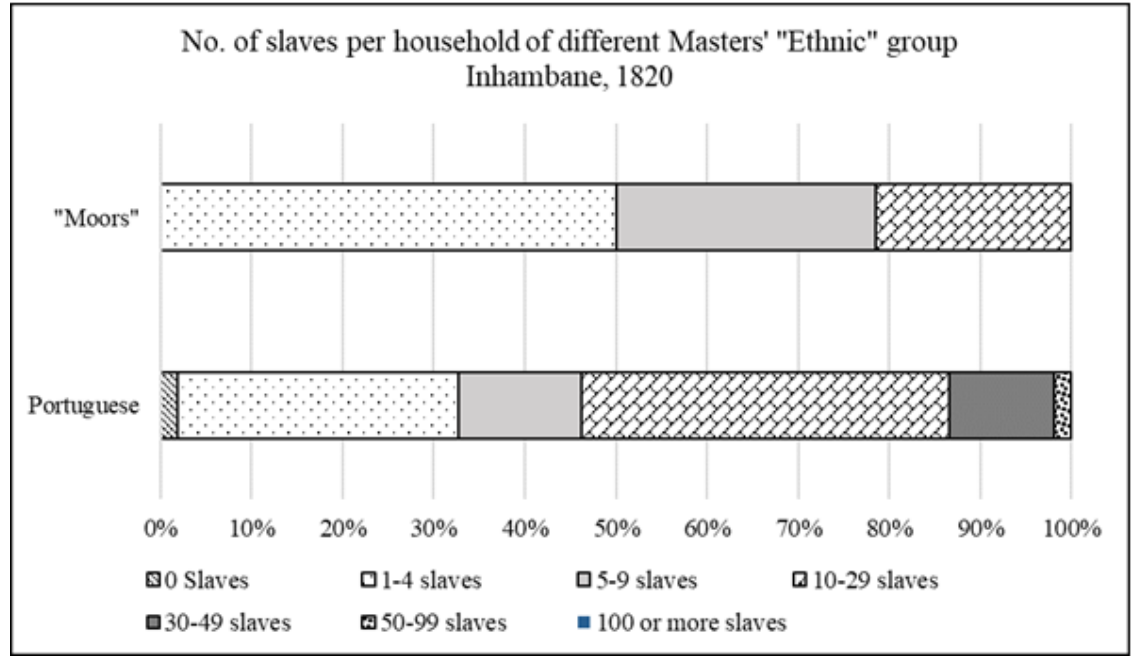

Sources: see legend to Graph 1. 
Graph 8

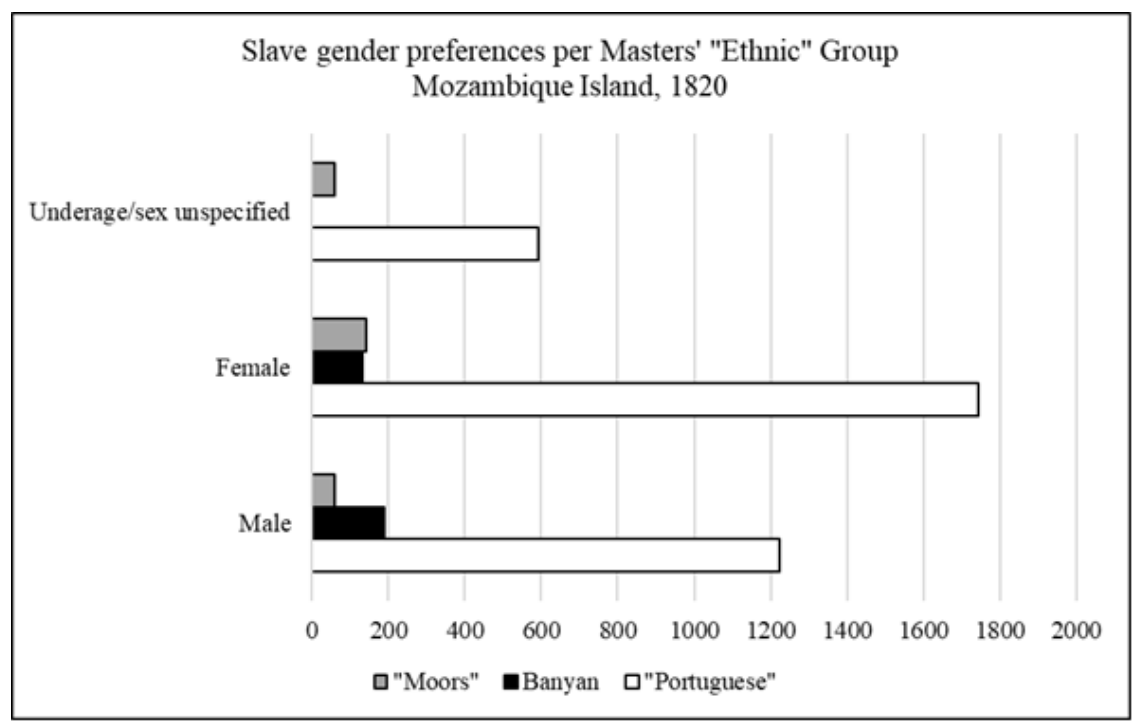

Sources: see legend to Graph 1.

Graph 9

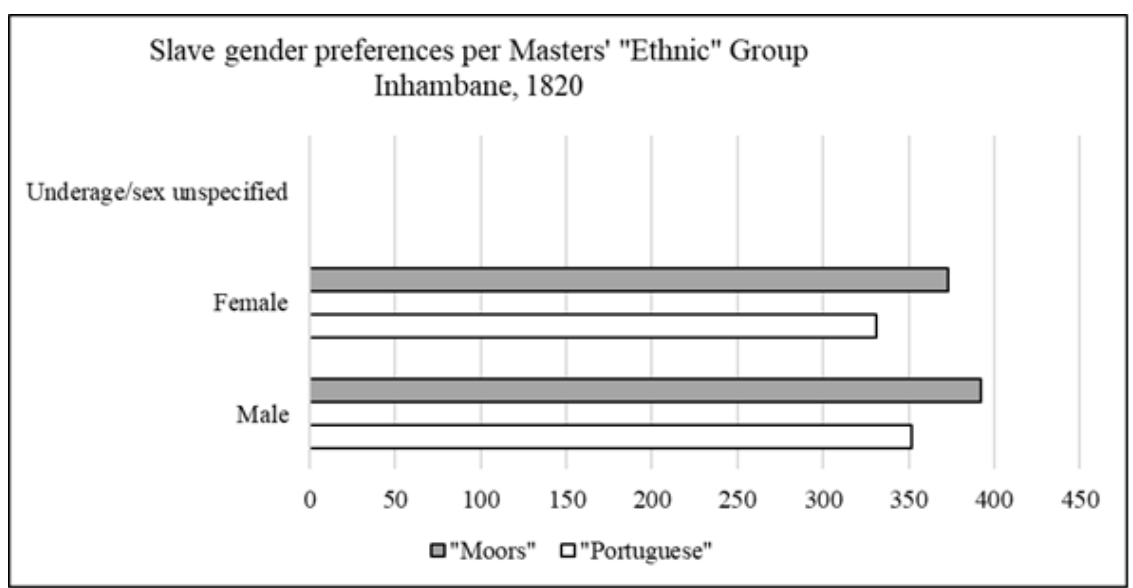

Sources: see legend to Graph 1.

What factors can explain the differences in slave ownership in the different cities and between the different communities there, the Portuguese, the Muslim, and the Banyans?

In our view there are five main factors and they are:

1. the activities developed by those groups for which slave labor was required; 
2. the possibilities of gaining access to land and the clienteles of dependents attached to those territories;

3. the level of wealth of the households of the three groups which would allow the heads of households to invest more or less money in slaves, or in the provision of services that would lead enslaved and nonenslaved Africans to live under their dependence and protection;

4. the value attributed to slave ownership. While in some cases slave holding would be regarded mainly as a status symbol suggesting power and prestige, in others it would be simply means to have available the labor needed for certain tasks; and

5. the value attributed to male and female slave labor by the slavemasters of the three different urban centers under analysis here. The different estimations of value and the ways male and female labor was perceived were directly linked to the dominant family systems in the regions under scrutiny and the positions and power of men and women in them, as well as in the home societies of the three groups. Each of these factors deserves individual detailed analysis in future research on forms of slavery and slave ownership in Mozambique.

\section{Conclusion}

To summarize, the evidence presented and discussed here suggests that in early nineteenth-century Mozambique the three main urban centers had approximately 10,000 inhabitants, the majority of whom were adult slave women. The free population was smaller and comprised a majority of people considered to be "Portuguese" either because of their Portuguese ancestry, their Catholic religion or their command of the Portuguese language. The Portuguese lived alongside communities of Muslims of Swahili origin and Banyan Hindu merchants in the port-towns of Inhambane and on Mozambique Island.

The three main groups formed the so-called free population and were the main slave owners in the urban spaces of nineteenth-century Mozambique, with the Portuguese inhabitants apparently being the main slave holders overall. Slave holding was especially high in Tete and Mozambique Island. The Banyan merchants based in Mozambique Island appear to have been the second largest group of slave holders while the Muslims seem to have owned a much more modest number of slaves.

Additionally, the population counts and household and estate surveys here under analysis suggest that the urban elites of Mozambique acquired their slaves in two distinct ways, either by purchase at slave markets or after taking leases on land which included dependent populations on it. Those dependents included not only enslaved but also non-enslaved African dependents.

The three groups of slave-masters showed different patterns of slave holding in terms of gender preferences. While Portuguese and Muslim slavemasters seem to have preferred adult women as slaves, the Banyan merchants 
had a clear preference for males. Among the households of Portuguese slavemasters regional differences can be discerned in gender preferences. While in Tete and Mozambique Island there were larger numbers of female slaves, in Inhambane that situation was reversed. A number of factors might have influenced the different patterns of slave holding found in nineteenth-century urban Mozambique. Those factors included levels of wealth, differences in economic activity and in the value attributed to slave ownership, as well as attitudes to male and female slave labor and male and female roles in the society and economy. However, further research is needed to shed more light on the topic.

The data discussed here also make clear that in early nineteenth century Mozambican towns and their outskirts local forms of slavery and other forms of dependence coexisted with the sort of modern and more global forms of slavery that emerged with the rise of the international slave markets of the Atlantic and Indian Oceans.

More importantly, the information analyzed and discussed here shows that in nineteenth-century Mozambique, like in other regions of the IOW:

- various forms of slavery coexisted, including client-slavery and chattel slavery, the latter mainly found in urban centers and the former in the agricultural outskirts of towns and rural areas;

- various forms of dependency existed side-by-side with slavery in all its forms, namely the patron-client relationship between powerful land-tenants and lords and non-enslaved African dependents, living and working in their own villages, but under the protection of those landlords, in exchange for tribute in labor and kind;

- and various forms slavery and dependency coexisted with the status of enslaved and non-enslaved being defined not so much by his/her access to freedom, but rather by the function he/she performed, and by the context in which he/she lived and worked.

This study brings to the fore therefore multiple similarities between Mozambique and other regions of the IOW and opens possibilities for further comparative research.

\section{Bibliography}

Allen, Richard, Slaves, Freedmen and Indentured Labourers in Colonial Mauritius (Cambridge: Cambridge University Press, 1999).

Alpers, Edward A., Ivory and Slaves: Changing Patterns of International Trade in East Central Africa to the Later Nineteenth Century (Berkeley: University of California Press, 1975).

Araújo, F., and, S. Alves, "A comunidade escrava de Leça da Palmeira seiscentista, Revista da Faculdade de Letras da Universidade do Porto História", 3rd series, 5 (2004): 193-210.

Barros, A.J.M., "O Porto e o Trato de Escravos no século XVI," Africana Studia 7 (2004): 31-51. 
Bauss, Rudy, “A Demographic Study of Portuguese India and Macau as well as comments on Mozambique and Timor, 1750-1850," The Indian Economic and Social History Review 34.2 (1997).

Candido, Mariana P., Fronteras de Esclavization: Esclavitud, Comercio e Identidad en Benguela, 1780-1850 (Mexico City: El Colégio de México, Centro de Estudios de Asia y Africa, 2011).

Capela, José, O tráfico de escravos nos portos de Moçambique, 1733-1904 (Porto: Edições Afrontamento, 2002).

Capela, José, "Slave Trade Networks in Eighteenth-Century Mozambique" in David Richardson and Filipa Ribeiro da Silva, eds., Networks and TransCultural Exchange: Slave Trading in the South Atlantic, 1590-1867 (Leiden/Boston: Brill, 2014), 165-194.

Fonseca, Jorge da, Escravos e Senhores na Lisboa Quinhentista (Lisboa: Edições Colibri, 2010).

Greene, Sandra E., Slave owners of West Africa: decision making in the Age of Abolition (Ghana, $19^{\text {th }}$ century) (Bloomington, Ind.: Indiana University Press, 2017).

Isaacman, Allen, Mozambique: The Africanication of a European Institution: The Zambezi Prazos, 1750-1902 (Madison, Wisc.: The University of Wisconsin Press, 1972).

Isaacman Allen, and Barbara Isaacman, "The prazeiros as transfrontiersmen: a study in social and cultural change," The International Journal of African Historical Studies 8.1 (1975), 1-39.

Isaacman Allen, and Barbara Isaacman, "Slavery and social stratification among the Sena of Mozambique: a study of the kaporo system," in S. Miers and I. Kopytoff, eds., Slavery in Africa: Historical and Anthropological Perspectives (Madison, Wisc.: The University of Wisconsin Press, 1977), 105-120.

Isaacman Allen, and Barbara Isaacman, Slavery and beyond: the making of men and Chikunda ethnic identities in the unstable world of south-central Africa, 1750-1920 (Portsmouth, NH: Heinemann, 2004).

Lahon, D., "O escravo africano na vida económica e social portuguesa do Antigo Regime," Africana Studia 7 (2004): 73-100.

Machado, Pedro, "A Forgotten Corner of the Indian Ocean: Gujarati Merchants, Portuguese India and the Mozambique Slave-Trade, c.1730-1830," Slavery \& Abolition 24.2 (2003), 17-32.

Machado, Pedro, Ocean Trade: South Asian merchants, Africa and the Indian Ocean, c. 1750-1850 (Cambridge: Cambridge University Press, 2014).

Mesquita, M.H.M. "Escravos em Angra no século XVII: uma abordagem a partir dos registos paroquiais," Arquipélago - História, 2nd series, 9 (2005): 209-230.

Newitt, Malyn, A history of Mozambique (Bloomington, IN: Indiana University Press, 1995).

Newitt, Malyn, Portuguese settlement on the Zambesi: exploration, land tenure and colonial rule in East Africa (London: Longman, 1973).

Pimentel, M. DO R., Viagem ao fundo das Consciencias. A escravatura na época Moderna (Lisboa: Bertrand, 1995). 
Ribeiro da Silva, Filipa, "Counting People and Homes in Urban Mozambique in the 1820s: Population Structures and Household Size and Composition," African Economic History 45:1 (2017): 46-76.

Ribeiro da Silva, Filipa, "From Church records to royal population charts: The birth of "modern demographic statistics" in Mozambique, 1720s1820s," Anais de História de Além-Mar 16 (2015): 17-50.

Rodrigues, Eugénia, Portugueses e Africanos nos Rios de Sena: Os Prazos da Coroa em Moçambique nos Séculos XVII e XVIII (Lisboa: Imprensa Nacional - Casa da Moeda, 2013).

Saunders, A. C. DE C. M., A Social History of Black Slaves and Freedmen in Portugal, 1441-1555 (Cambridge: Cambridge University Press, 1982).

Sheldon, Kathleen E., Pounders of Grain: A History of Women, Work, and Politics in Mozambique (Portsmouth, NH, 2002).

Wagner, Ana Paula, População no Império Português: Recenseamentos na África Oriental Portuguesa na segunda metade do século XVIII (Ph.D. diss., Universidade Federal do Paraná, Curitiba, 2009). 